\title{
Regerach article: A comparative study on job satisfaction of women extension personnel
}

\author{
C.N. ANSHIDA BEEVI, MONIKA WASON, R.N. PADARIA, PREMLATA \\ SINGH, PRAMOD KUMAR AND ELDHO VARGHESE
}

Article Chronicle :

Received :

19.07.2017;

Accepted :

03.08.2017

KEY Words:

Job, Satisfaction, Extension personnel, State Department of Agriculture

Author for correspondence :

\section{C.N. ANSHIDA BEEVI}

ICAR-CRIDA,

HYDERABAD

(TELANGANA) INDIA

Email : anshidashref@

gmail.com

See end of the article for

authors' affiliations
SUMMARY : Gender equality and empowered women are catalysts for multiplying development efforts. Women often face discrimination and persistent gender inequalities, with some women experiencing multiple discrimination and exclusion because of factors such as ethnicity or caste. Now-a-days, women even face discrimination in working condition which can affect their job performance and ultimately organizational performance. Hence, job satisfaction is an important factor affecting the job performance of employees in an organization. For achieving organizational effectiveness, it plays a crucial role. Adekanbi (2000) in his study showed that employees with high level of job involvement are satisfied with their jobs. In this study, an attempt has been made to analyze the job satisfaction level of women extension personnel working in different organizations like Kerala State Department of Agriculture and Vegetable and Fruit Promotion Council Keralam. For this study Agricultural Officers, Agricultural Assistants and VFPCK extension personnel consisting a sample of 210 respondents was studied. Job satisfaction was measured with the scale developed for the study. Almost 31.67 per cent of women agricultural officers were highly satisfied with their job while, only 20.83 per cent agricultural assistants and 13.33 per cent VFPCK were highly satisfied. Hence, the study concluded that job satisfaction level is significantly different among hierarchy and organizations.

How to cite this article : Beevi, C.N. Anshida, Wason, Monika, Padaria, R.N., Singh, Premlata, Kumar, Pramod and Varghese, Eldho (2017). A comparative study on job satisfaction of women extension personnel. Agric. Update, 12(TECHSEAR-7) : 1914-1917; DOI: 10.15740/HAS/AU/12.TECHSEAR(7)2017/1914-1917. 